\title{
NANOMATERIALS FOR GOOD INDOOR ENVIRONMENTS: ELECTROCHROMICS, SENSORS AND PHOTO-CATALYSTS
}

\section{NANOMATERIALES PARA AMBIENTES CERRADOS BUENOS: ELECTROCROMISMO, SENSORES Y FOTOCATALISIS}

\author{
Claes-Göran Granqvist ${ }^{1}$
}

\begin{abstract}
Nanomaterials can be used in a number of technologies in order to create good indoor environments. This paper takes a unified view on this issue from a solar-energy-based perspective and specifically considers electrochromics for achieving good day-lighting jointly with energy efficiency, sensors aimed at air quality assessment, and photo-catalysis for air cleaning. Recent results, mainly from the author's laboratory, are reported for all of these areas. Work performed by PhD students and other collaborators from Peru are highlighted.
\end{abstract}

Keywords.- Nanomaterials, Electrochromics, Photo-catalysis, Air cleaning.

\section{RESUMEN}

Los Nanomateriales pueden ser utilizados en una gran variedad de tecnologías con el objeto de crear buenas condiciones en ambientes interiores. Este articulo toma una visión unificada de este concepto desde el punto de vista de las tecnologías basadas en energía solar y específicamente considera materiales electrocrómicos para conseguir un control adecuado de la luz del día, juntamente con eficiencia energética; sensores con el objetivo de monitorear el aire y fotocatálisis para la limpieza del aire. Resultados recientes, obtenidos mayormente por los investigadores de este laboratorio, son reportados en todas estas áreas en el presente artículo. Los trabajos realizados por estudiantes, de doctorado y otros colaboradores del Perú son resaltados.

Palabras clave.- Nanomateriales, Electrocrómicos, Foto catálisis, Limpieza de aire.

\section{INTRODUCTION}

Modern Man normally spends some $90 \%$ of his time inside buildings and vehicles. The quality of the indoor environment hence is of great importance, and more and more energy is used to maintain it at a level that is both comfortable and healthy. Globally, some $30-40 \%$ of the primary energy is used for heating, cooling, ventilation, and lighting of buildings, as found in a recent, comprehensive study by the United Nations Environment Programme [1].

The purpose of this article is to emphasize that new nanomaterials offer a number of attractive alternatives to use solar energy to maintain a benign indoor environment. Specifically, we will consider three options below: (i) heating, cooling, lighting, and visual contact between indoors and outdoors, which calls for "smart windows" capable of changing their throughput of visual light and solar irradiation by utilizing electrochromic (EC) materials characterized by a specific nanostructure, thereby avoiding excessive solar heating while taking advantage of this heating when there is a need for such [2 y 3]; (ii) cheap nanomaterials-based sensors for air quality, used to accomplish energy efficient "ventilation on demand"; and (iii) nanostructured photocatalysts that can be used for solar-energyrelated air purification [4 y 5] and consequently reduced demand for ventilation. The sensor technology is not, in a strict sense, related to solar energy, but its intimate relationship to air purification makes it natural to include sensors in this brief exposition.

\footnotetext{
${ }^{1}$ Dr. del Department of Engineering Sciences, The Ångström Laboratory, Uppsala University.
} 
Most of the results summarized below are from recent investigations by the author and his collaborators. Work by the Peruvian collaborators Estrada, Talledo, Gutarra, Gómez, Rodriguez, Solis, Reyes and Luyo, named in the order the collaborations commenced in time, is referred to. The presentation is an adaptation and update on a previous paper [6].

\section{ELECTROCHROMICS FOR ENERGY EFFICIENT 'SMART WINDOW}

Figure 1 shows a prototype of a "smart window" with four $30 \times 30 \mathrm{~cm}^{2}$ EC foils [3, 7 y 8 ] mounted between glass panels.

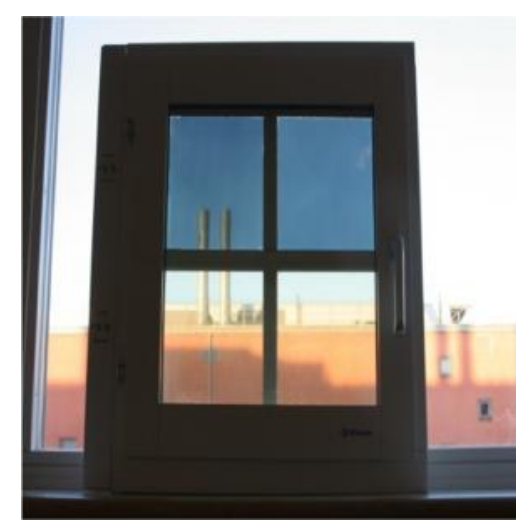

Fig. 1 Smart window prototype with four $30 x$ $30 \mathrm{~cm}^{2}$ panels.

The upper two panels are in their fully colored state while the lower two are in their fully bleached state. Each of the panels can shift gradually and reversibly between the dark and transparent states in about a minute, i.e., during the time it takes for the human eye to adapt to different lighting conditions. It is important to note that the window maintains its primary function-that of providing unmitigated visual indoors/ outdoors contact-irrespective of the state of coloration. The windows do not give privacy, though.

\section{General device design and materials}

The EC "smart window" has a principle resemblance to a thin-film electrical battery, as evident from Fig. 2. The device has five superimposed layers on a transparent substrate, typically of glass or flexible polyester foil, or positioned between two such substrates in a laminate configuration [2].

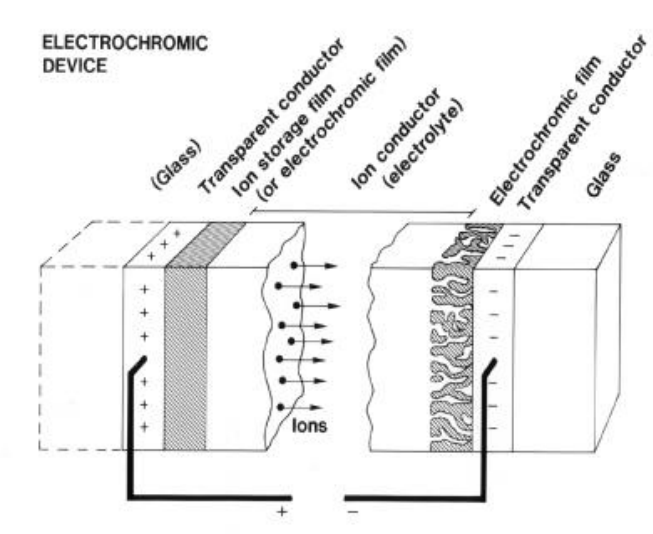

Fig. 2 Prototype EC device, showing transport of positive ions under the action of an electric field. From [2].

The outermost layers are transparent electrical conductors, typically of $\mathrm{In}_{2} \mathrm{O}_{3}: \mathrm{Sn}$ (i.e., Indium Tin Oxide, ITO) [9 y 10]. One of these layers is coated with an EC film, whereas the other one is coated with an ion storage film, with or without EC properties. Both of these films must comprise nanomaterials characterized by well specified nanoporosities. A transparent ion conductor (electrolyte) is at the middle of device and joins the EC and ion storage films. A voltage pulse applied between the transparent electrodes leads to charge being shuttled between the EC and ion storage films, and the overall transparency is thereby changed. A voltage pulse with opposite polarity-or, with suitable material combinations, short circuiting-makes the device regain its original properties. The optical modulation requires a DC voltage of as little as 1 to $2 \mathrm{~V}$. The charge insertion into the EC film(s) is balanced by electron inflow from the transparent electrode(s); these electrons can make intervalency transitions (i.e., yield polaron absorption), which constitutes the basic reason for the optical absorption.

Regarding materials in EC devices, the ITO can be replaced by $\mathrm{ZnO}: \mathrm{Al}, \mathrm{SnO}_{2}: \mathrm{F}$, or similar materials [10-12]. The global availability of indium is larger than issome times anticipated [13], and ITO possibly may be the option even for large-scale production of EC-based "smart windows".

The EC film is $\mathrm{WO}_{3}$ in almost all devices for window applications. Usually these are films made by physical or chemical deposition 
techniques but, as shown by Solis et al., nanoparticulate $\mathrm{WO}_{3}$ - made by a gas deposition technique to be further discussed in Sec. 3 below-offers some interesting possibilities [14]. EC properties of $\mathrm{TiO}_{2}$ : $\mathrm{F}$ were investigated by Gutarra et al. [15].

There are many possibilities for the counter electrode in an EC device [2,3, 16 y 17]. Early work frequently used $\mathrm{V}_{2} \mathrm{O}_{5}$-based films, of a type that has been studied in detail by Talledo et al. [18-23].NiO-based films were developed by Estrada et al. [24 y 25].In recent work on EC devices, there has been much interest in films based on $\mathrm{IrO}_{2}$ and $\mathrm{NiO}$. $\mathrm{IrO}_{2}$-based alternatives are inherently expensive, but good EC properties are maintained after dilution with less costly $\mathrm{Ta}_{2} \mathrm{O}_{5}$ [26]. Figure 3 shows a high-resolution transmission electron micrograph of an $\mathrm{IrO}_{2}$ film from which a well defined nanostructure with nanometer-sized crystallites is apparent [27]; films containing $\mathrm{Ta}$ displayed a more finegrained structure.

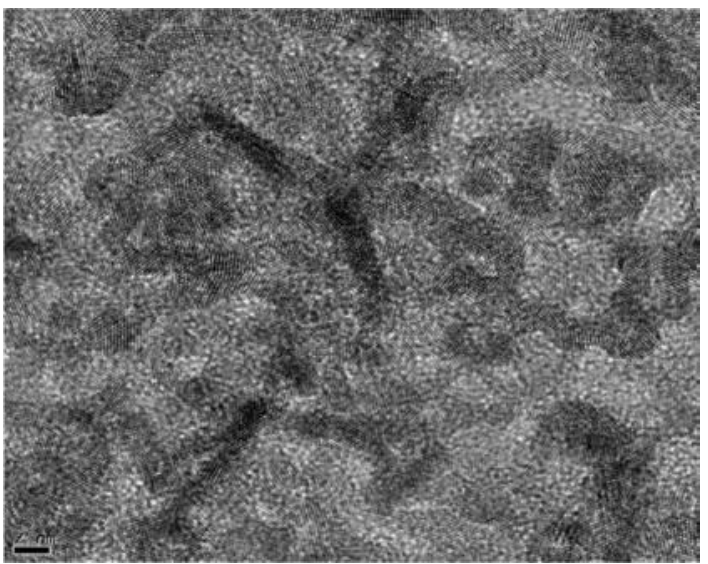

Fig. 3 High resolution transmission electron micrograph of an $\mathrm{IrO}_{2}$ film made by reactive magnetron sputtering. From [27].

NiO-based films combine moderate cost with excellent optical properties, especially when the $\mathrm{NiO}$ is mixed with another oxide characterized by a wide band gap such as $\mathrm{MgO}$ or $\mathrm{Al}_{2} \mathrm{O}_{3}$ [28].

EC devices can make use many different electrolytes, either being hydrous oxides exhibiting proton conduction, polymers with ion conduction due to added salts, or ionic liquids.
EC devices have been discussed a long time, ever since the display-type devices presented shortly after the discovery of electrochromism in $\mathrm{WO}_{3}$ films [29 y 30]. Generally speaking, the progress of technologies based on electrochromism has been slow, however, which may be associated with the necessity of simultaneously mastering a range of non-conventional technologies as follows: $(i)$ the ITO must combine excellent electrical conductivity with very low optical absorption, which is challenging in particular for films on temperature sensitive substrates such as polyester; (ii) the EC and counter electrode films must exhibit well specified nanoporosities over large areas, and this requires non-standard coating technologies; (iii) regarding the EC device as a type of thin film battery, it is evident that charge insertion/extraction and charge balancing must be accomplished by properly controllable and industrially viable techniques, such as gas treatments [31]; (iv) the electrolyte must combine good ion conductivity with adhesiveness and high transparency for ultraviolet irradiation; and $(v)$ long-term cycling durability demands adequate strategies for voltage and current control during coloration/bleaching, just as it does for charging/discharging of batteries. All of these challenges can be successfully met, however, and EC technology finally may emerge as a technology for large-area, large-scale applications [32].

Film porosity on the nano scale is necessary, as stressed above. Virtually any thin film technology may be capable of achieving the desired properties, with more or less difficulty. Regarding sputtering [33], the deposition parameters should be confined to those giving "zone 1" films in the well known Thornton diagram [34].

The specific nano-topography then accomplished has been denoted "parallel penniform" in work by Rodriguez et al., a designation that is appropriate at least in the case of some $\mathrm{TiO}_{2}$ films [35]. Figure 4 shows a cross-sectional image of such a film. The combination of large internal surface and contiguity makes this structure ideally suited for applications in electrochromics and in other types of solid state ionic devices. 


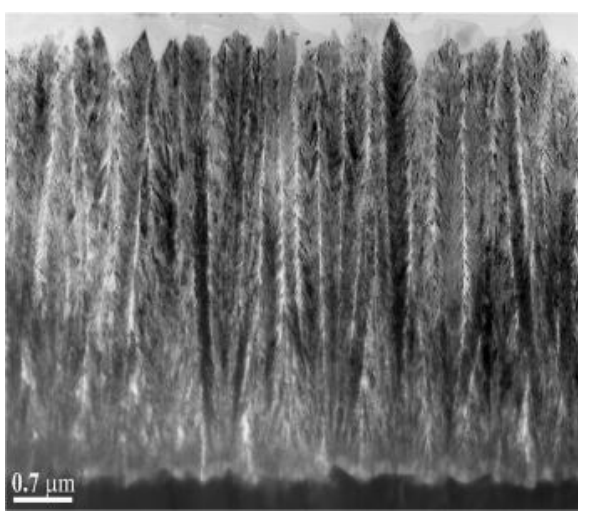

Fig. 4 High resolution transmission electron micrograph of a cross section through a $\mathrm{TiO}_{2}$ film made by reactive magnetron sputtering. From [35].

\section{Device data}

Figure 5 shows characteristic data for a $5 \mathrm{x} 5 \mathrm{~cm}^{2}$ flexible $\mathrm{EC}$ foil incorporating $\mathrm{WO}_{3}, \mathrm{NiO}$ modified by addition of a wide band gap oxide such as $\mathrm{MgO}$ or $\mathrm{Al}_{2} \mathrm{O}_{3}$, PMMA-based electrolyte, and ITO films [7 y 8].

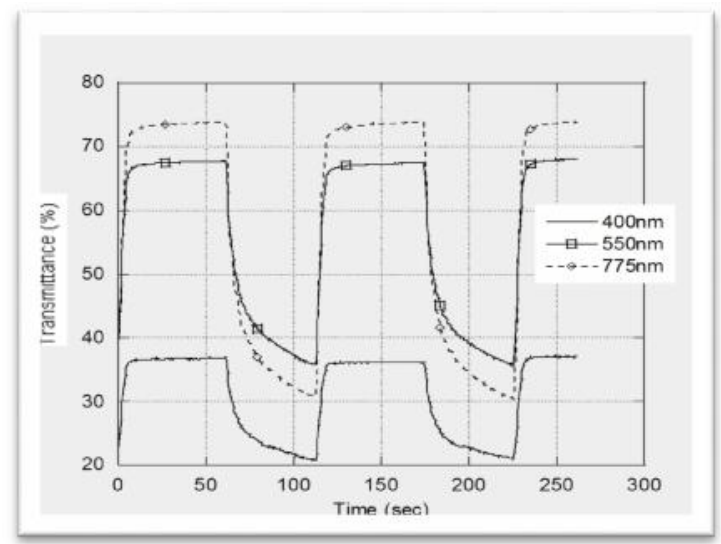

Fig. 5 Time-dependent transmittance during coloration/bleaching of an EC device, recorded at three wavelengths. From [6].

The mid-luminous transmittance $\left(T_{550}\right.$, where the subscript denotes the wavelength in nanometers) rapidly attains $\sim 68 \%$ upon bleaching and drops to $\sim 36 \%$ during a coloration period of 50 s. Still lower values can be reached with extended coloration times. The modulation is smaller, but still significant, for blue light $\left(T_{400}\right)$ whereas it is larger for red light $\left(T_{775}\right)$. The substantial transmittance at the blue end of the spectrum is associated with the addition to the $\mathrm{NiO}$. Durability was manifest for several tens of thousands of coloration/bleaching cycles. The open circuit memory is excellent and the optical properties are maintained virtually unchanged for many hours

\section{Energy efficiency and indoor comfort}

The energy efficiency inherent in the "smart windows" technology has been difficult to come to grips with, partly since the most fundamental function of a window or glass façade - that of providing unmitigated visual contact between indoors and outdoors-has not always been fully appreciated. From a strict energy perspective, it may be beneficial to eliminate the windows entirely, but this is highly detrimental to the wellbeing and working efficiency of the persons using the building who would rather prefer a panoramic view of their ambience. Energy efficiency of the windows hence must be reached with full understanding of their need to provide transparency.

A "back-of-an-envelope-analysis" of the energy efficiency [36] can be made by first setting the solar energy falling onto a vertical surface per year to $1000 \mathrm{kWh} / \mathrm{m}^{2}$. This represents a nominal value, and more correct numbers for Southfacing/North-facing/horizontal surfaces are $850 / 350 / 920,1400 / 450 / 1700$, and 1100/560/1800 $\mathrm{kWh} / \mathrm{m}^{2}$ for Stockholm (Sweden), Denver (U.S.A.), and Miami (U.S.A.), respectively.

Half of this, i.e., $500 \mathrm{kWh} / \mathrm{m}^{2}$, corresponds to visible light. This latter number is used in the analysis since infrared radiation can be eliminated-at least in principle-by use of known technology for "solar control" that does not require variable transmittance [11 y 12]. If the transparency can be altered between 7 and 75 $\%$ [36] — which is by no means unlikely given further EC technology development-the difference between having the window constantly colored and constantly bleached is $340 \mathrm{kWh} / \mathrm{m}^{2}$.

Actually, the stated range of optical modulation can be accomplished already today [36], but at the expense of slow dynamics and some degradation under extended cycling. The next issue is then to contemplate when the "smart window" should be colored and when it should be bleached. With physical presence of persons as the basis of the control strategy, the question is when a room is in use-or, more precisely, the fraction of the solar energy that enters when 
nobody is present. Considering that a normal (office) room is empty during vacations, holidays and weekends, early mornings and late afternoons (when the sun stands near the horizon), etc., it may be a conservative estimate that $50 \%$ of the energy enters when no one is present to look through the window. This estimate then yields that $170 \mathrm{kWh} / \mathrm{m}^{2}$ is the amount of energy saved annually by adopting the given control strategy. In order to answer the question whether this savings is significant or not, we can note that $17 \%$ is a typical value for today's best thin-film solar (sub) modules [37]. Thus these solar cells would be able to generate $170 \mathrm{kWh} / \mathrm{m}^{2}$ if they were to replace the "smart window" in the example. Clearly the analogy between energy savings in "smart windows" and energy generation in solar cells is not tied to the choice of the incident solar energy being 1000 $\mathrm{kWh} / \mathrm{m}^{2}$ but applies generally irrespectively of the orientation of the surface under examination. The "smart window" saves thermal energy, but if a cooling machine for providing comfort cooling - operating with an efficiency of $300 \%$, say-runs on electricity generated with an efficiency of $33 \%$ then the analogy becomes perfect. This latter consideration implies that one employs a "national scenario" for the energy, with a "Coefficient-of-Performance" ("COPfactor") equal to unity.

A complementary and more specific (though less intuitively evident) view on the energy efficiency of "smart windows" can be reached from the viewpoint of building simulations, which have been completed recently [38 y 39]. Specifically, calculations for a standard office module with well defined size, window area, lighting demand, occupancy, equipment, etc., showed that the energy savings potential was considerable for the cooling load. The studied office block was oriented with one façade facing South and one facing North, and the simulations were performed with climate data applicable to Rome (Italy), Brussels (Belgium), and Stockholm (Sweden). When using "smart windows" instead of conventional static solar control windows, the energy for space cooling, on an annual basis, could be reduced by as much as 40 to $50 \%$. The amount of saved energy is obviously climate dependent. In moderately warm climates, such as those of Brussels and Stockholm, the number of days with very high outdoor temperatures is relatively small but the energy required for balancing excessive solar energy inflow nevertheless is substantial, and an interesting result of the simulations was that the cooling power could be reduced so that air conditioning may be completely avoided when "smart windows" are used, thus indicating that the additional cost for "smart windows "can be more than compensated by the elimination of an air conditioning system. Other analyses of the energy efficiency inherent in EC-based fenestration have been presented recently [40 y 41].

Irrespectively of the analysis being intuitively based or rooted in elaborate energy simulations, the energy efficiency is large and the "smart windows" technology stands out as a very significant one for alleviating our current dependence on non-renewable energy resources. But there are other assets of great importance as well. Thus the ability to change the transparency at will makes it possible to create an ambience with enhanced indoor comfort, characterized by less glare and thermal stress, when the room is in use.

\section{Nanoparticle oxide films for gas sensing}

Health-related problems ensuing from the indoor environment are issues of frequent public concern since pollution of air inside buildings may lead to discomfort for the users and in some cases may even be a health hazard. Low air quality can result from poor ventilation, pollutants and microorganisms from inadequately maintained ventilation systems, gaseous odors emitted from building materials, tobacco smoke, etc. The indoor air contains a wide range of volatile organic compounds (VOCs) with different chemical and physical properties. Over 900 chemical compounds have been detected in indoor air [42]. The concentration of these VOCs depends on type of activity in the rooms, ventilation rates, number of persons present, furniture, etc. A number of these VOCs have a higher concentration indoors than outdoors [43], as highlighted by a recent EU study [44]. Exposure to VOCs has been suggested to cause the "Sick Buildings Syndrome", viz., a diverse affliction that includes symptoms such as mucous irritation (e.g., irritation of the eyes, nose and throat), skin irritation as well as odor and taste complaint, neurotoxin effects (e.g., fatigue, lethargy, headache, nausea, as well as reduced memory and concentration), and nonspecific 
reactions (e.g., chest sounds and asthma-like symptoms) [45 y 46].

Clearly air quality assessment is an issue of great significance, which calls for affordable gas sensors capable of indicating when ventilationwhich in most cases requires electrical energyis necessary. The idea is hence to accomplish "ventilation on demand" rather than having a prescribed number of air changes per hour. This section reviews some recent data for nanoporous oxide films whose electrical properties are altered when in contact with gaseous molecules or airborne microorganisms. Films based on $\mathrm{WO}_{3}$ are of much interest, just as in the case of EC devices, and in fact electrochromics and sensorics have much in common.

A common problem with nanoparticle-based sensors is their long-term drift of the electrical resistance. One way to improve on this is to employ advanced gas deposition (AGD) for making the particulate films; another is to exploit resistance fluctuations (noise) as a base for gas sensing, as mentioned further below.

\section{Nanoparticle deposition}

Gas deposition as a method for the production of nanocrystalline and nanoporous films is based on the evaporation of a substance under stable conditions into a gas, which cools the vapor so that nucleation and growth of particles takes place, and subsequent deposition of the particles on a substrate [47].

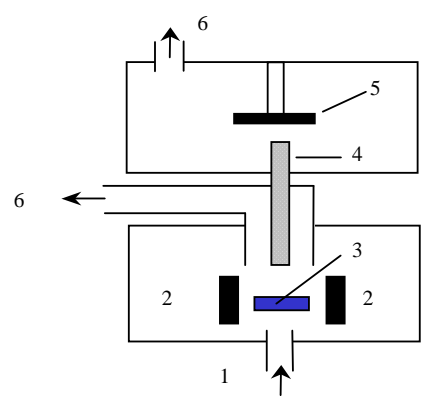

Fig. 6 Principle for AGD of nanoparticles. A gas is introduced at (1) and forms a laminar flow in the lower chamber in which a heater (2) produces a vapor of a substance (3); the particles that are formed are transferred via a tube (4) into a vacuum chamber and are deposited on a substrate (5). Excess gas is removed by outlets (6). From [6].
Figure 6 illustrates an AGD unit in which the particles-formed in a laminar gas flow in the lower chamber-are transferred to the upper vacuum chamber via a tube ending with a nozzle and allowing deposition of uniformly sized particles onto a substrate that can be moved in different directions so that particulate layers are formed. Doped and mixed oxide films can be produced analogously using AGD with two vapor sources having individual transfer pipes [48].

The technique is discussed in some detail elsewhere [49 y 50]. The particles are known to exhibit a well defined log-normal size distribution with narrow width [51].

Gas sensing utilizing layers of $\mathrm{WO}_{3}$ particles made by AGD has been investigated by Solis et al. [52-54] and subsequently by Reyes et al. [5558], and analogous studies of $\mathrm{NiO}$ particles were carried out very recently by Luyo et al. [59]. Figure 7 shows electron microscopy images of a sample of $\mathrm{WO}_{3}$ nanoparticles from the work by Reyes et al. [57]. More general studies have been reported also by the same authors [60 y 62].

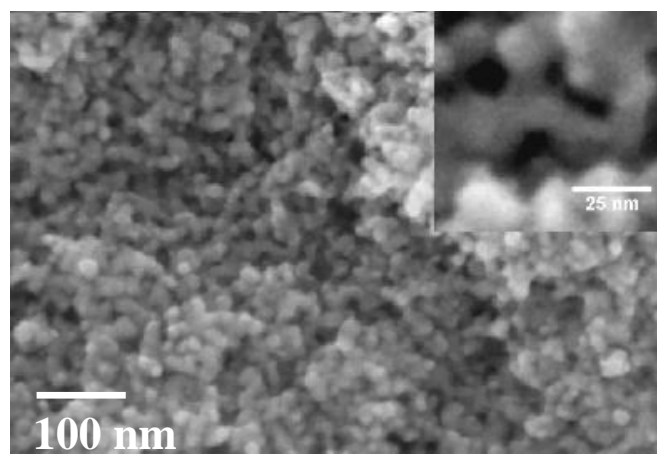

Fig. 7 Scanning electron micrograph of a $\mathrm{WO}_{3}$ nanoparticle film made by $A G D$, with inset showing a magnification. From [57].

\section{Gas sensing using temperature-modulation}

Low-level detection of ethanol and $\mathrm{H}_{2} \mathrm{~S}$ were accomplished with temperature-modulated gas sensors comprising nano-particle $\mathrm{WO}_{3}$ films of the kind shown in Fig. 7 [63 y 64]. Figure 8 illustrates the change in the resistance $R$ as a sensor was modulated at $\tau_{\mathrm{o}}=260 \pm 50^{\circ} \mathrm{C}$ and exposed to $20 \mathrm{ppm}$ of ethanol, and modulated at $\tau_{\mathrm{o}}=200 \pm 50^{\circ} \mathrm{C}$ and exposed to $200 \mathrm{ppb}$ of ethanol. The unambiguous change in the temperature modulation $R$ even in the ppb range 
is noteworthy and attests to the great sensitivity of the technique. Similar measurements showed that as little as $20 \mathrm{ppb}$ of dry $\mathrm{H}_{2} \mathrm{~S}$ could be detected, as illustrated in Fig. 9.
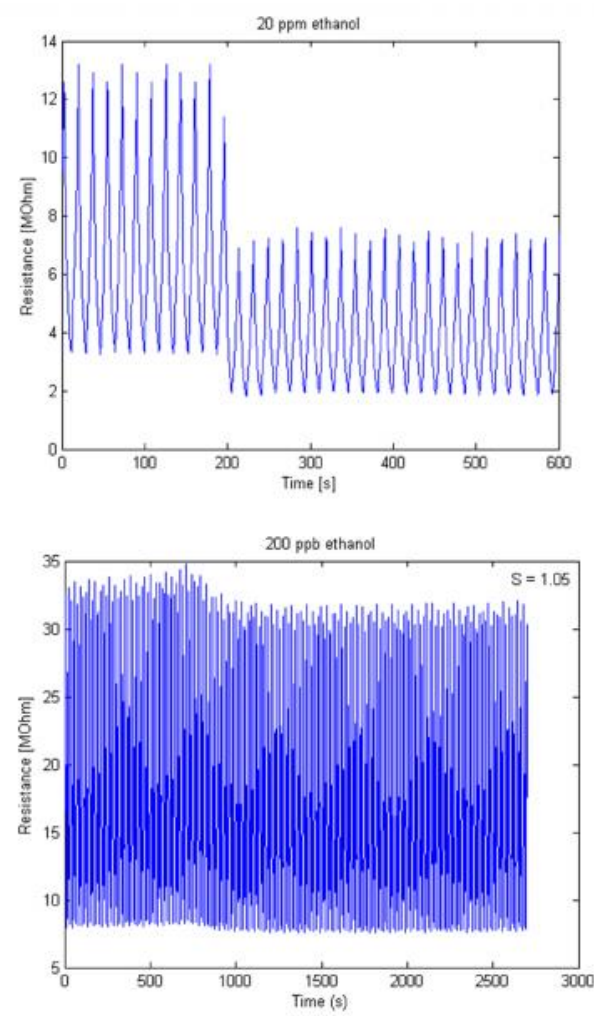

Fig. 8 Temperature-dependent resistance of a $\mathrm{WO}_{3}$ nanoparticle sensor exposed to the shown amounts of ethanol and modulated at $260 \pm 50^{\circ} \mathrm{C}$ (upper panel) and $200 \pm 5$ ${ }^{\circ} \mathrm{C}$ (lower panel). From [64].

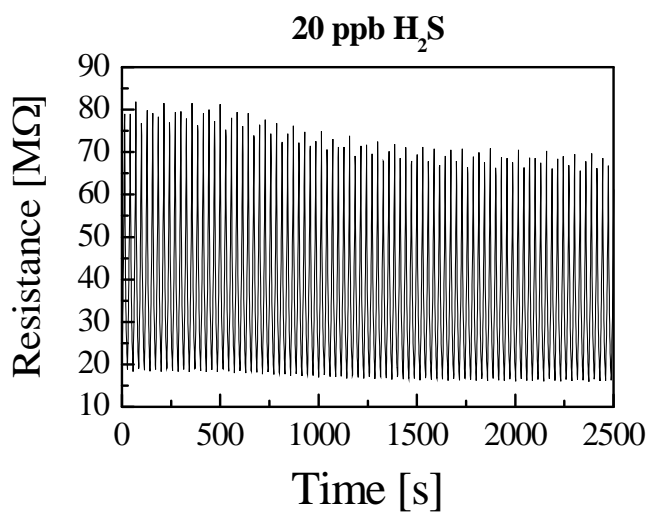

Fig. 9 Temperature-dependent resistance of a $\mathrm{WO}_{3}$ nanoparticle sensor exposed to 20 ppb of $\mathrm{H}_{2} \mathrm{~S}$ and modulated at $200 \pm 50^{\circ} \mathrm{C}$. From [6].
Defining the sensitivity as $S=R_{\text {air }} / R_{\text {gas }}$, it was found that $S$ obeyed a second-degree relationship with regard to $\tau_{0}$, while $S$ was proportional to the gas concentration [64]. The periodic sensor signals were decomposed by fast Fourier and discrete wavelet transforms, and the ensuing data were used as inputs into various pattern recognition methods. It was then clear that not only excellent sensitivity was achievable but also good selectivity between the gaseous species [63 y 64].

Another recently developed sensing principle uses resistance fluctuations to provide ultrasensitive gas detection with excellent selectivity so that, in principle, a single sensor is capable of detecting a multitude of gases [65]. Work of this kind has been reported by Reyes et al. [55] and Solis et al. [60 y 61]. Recent data on Pd-doped nano-crystalline $\mathrm{WO}_{3}$ films made by AGD showed that the fluctuations (i.e., the stochastic signal) were capable of yielding a 300 times larger sensitivity for ethanol detection than the classical resistance measurement [48]. These aspects of gas sensing fall outside the scope of this article, though.

\section{Nanoparticle oxide films for photo-catalytic air purification}

A novel way to accomplish air cleaning is to use photo-catalytic surfaces [4, 5 y 66]. Polluted air passes over the photo-catalytic surface, which is irradiated by light. Pollutants adsorbed on the surface are then decomposed into harmless, odorless, or less toxic compounds. Thus, rather than simply changing the phase and concentrating the contaminant, the absolute toxicity of the proximity environment is reduced, thereby allowing the photo-catalytic surface to operate as a self-cleaning coating with sunlight and/or existing indoor illumination as the only energy source. Hitherto such surfaces have been used on the outside of windows and façades in order to decrease the need for periodic cleaning $[4,5,67-69]$. However it is possible to employ surface coatings on the inner pane of multi-pane windows or transparent façade claddings in order to improve the indoor air quality. The hypothesis is that harmful substances in the air will undergo catalytic reactions on the active coating due to irradiation by the UV part of the solar radiation entering the outer, UV-transparent, pane of the window, and that complete degradation of such 
substances will take place or that less toxic substances will be formed.

Photo-catalysis is a well-known phenomenon [4,5 y 66]. Essentially, photons create electronhole pairs at the surface of a photo-catalytically active material such as $\mathrm{TiO}_{2}$ or $\mathrm{WO}_{3}$ and the ensuing radicals oxidize molecules or microorganisms residing on the surface so that, eventually, $\mathrm{CO}_{2}, \mathrm{H}_{2} \mathrm{O}$, and simple inorganic mineral salts are all that remain. Rodriguez et al. have reported work on photocatalysis using $\mathrm{TiO}_{2}$ films [70 y 71], as well as more general investigations of such films [35,72 y 73].

The most investigated photo-catalyst is anatasetype $\mathrm{TiO}_{2}[4,5$ y 66]. Its band gap is $\sim 3.2 \mathrm{eV}$, i.e., wide enough that mainly ultraviolet radiation with wavelengths below $390 \mathrm{~nm}$ is effective, which limits the applicability for photo-catalytic purification of indoor air. A second generation of visible active materials is currently sought for [74]. Among them, nitrogen doped $\mathrm{TiO}_{2}$ is able to diminish the band gap, as demonstrated recently [75-78], and films of $\mathrm{TiO}_{2-x} \mathrm{~N}_{x}$ are of much interest for air purification.

Figure 10 shows the evolution of the optical absorption when reactive DC magnetron sputtering of Ti was carried out in $\mathrm{Ar}+\mathrm{O}_{2}+\mathrm{N}_{2}$, with the $\mathrm{N}_{2}$ fraction denoted $\Phi$. It is apparent that a small amount of $\mathrm{N}_{2}$ leads to visible light absorption [78].

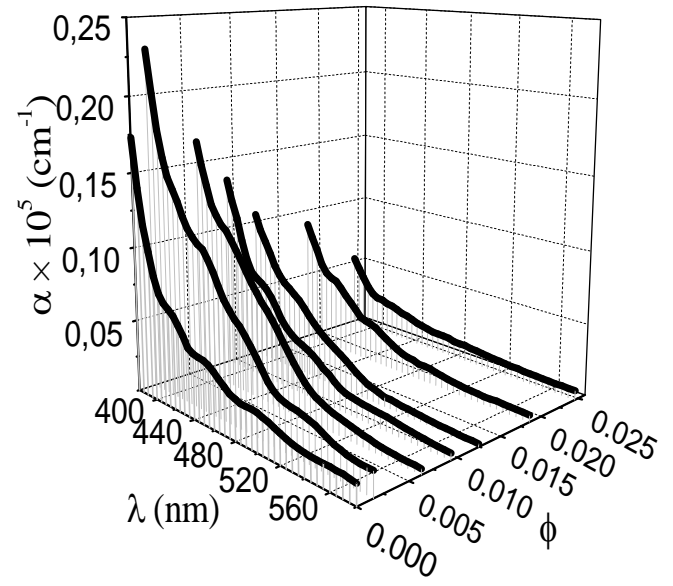

Fig. 10 Optical absorption coefficient a versus wavelength $\lambda$ for $\mathrm{TiO}_{2-x} N_{x}$ films produced with the shown magnitudes $\Phi$ of $\mathrm{N}_{2}$ in the sputter plasma. From [78].

\section{Summary}

This brief review has delineated a set of technologies with a joint bearing on solar energy as a basis for producing energy efficient, comfortable, and healthy indoor environments in buildings. The focus has been on work carried out in the author's laboratory, especially as it regards research performed by Peruvian students and post docs. Electrochromics is used to give user-adapted day-lighting and avoid glare and thermal discomfort due to excessive solar influx. Solar photo-catalysis is used for air purification, and the demand for ventilation is monitored via sensors for air quality. Nanoporous transition metal oxides are employed for all of the various functions; this clearly shows that the research field outlined in this brief review has a high degree of internal consistency and even, in many cases, makes good use of the same type of materials.

The analogy can be extended also to other energy related applications. Thus research on dye sensitized solar cells incorporating nanoporous $\mathrm{TiO}_{2}$ films has been done by Gómez et al. [7984].

\section{REFERENCES}

1. UNEP, Buildings and Climate Change: "Status, Challenges and Opportunities", United Nations Environment Programme, Paris, France, 2007.

2. Granqvist, C.G., "Handbook of Inorganic Electrochromic Materials", Elsevier, Amsterdam, The Netherlands, 1995 (reprinted 2002).

3. Niklasson, G.A., Granqvist, C.G., "Mater, J.,Chem”. 17 pp. 127, 2007.

4. Fujishima, K., Hashimoto, T., Watanabe., "TiO ${ }_{2}$ ", Photocatalysis, Bkc, Tokyo, Japan, 1999.

5. Fujishima, X. Zhang, D. A. "Tryk, Surf". Sci. Rep. 63 pp. 515, 2008.

6. Granqvist, C.G., Azens, A., Heszler, P., Kish, L.B., Österlund, L.,"Solar Energy Mater". Solar Cells 91, pp. 355, 2007.

7. Azens, G., Gustavsson, R., Karmhag, C.G., Granqvist.,"Solid State Ionics" 165 pp. 1, 2003

8. Azens, A. Avendaño, J. Backholm, L. Berggren, G. Gustavsson, R. Karmhag, G.A. Niklasson, A. Roos, C.G. Granqvist, "Mater. Sci". Engr. B 119, pp.214, 2005. 
9. Granqvist, C.G., Hultåker, A.,’Thin Solid Films" 411, pp. 1, 2002.

10. Granqvist, C.G."Solar Energy Mater". Solar Cells 91, pp. 1529, 2007.

11. Granqvist, C.G., in: "Materials Science for Solar Energy Conversion Systems", C.G. Granqvist (Ed.), Pergamon, Oxford, UK, pp. 106-167, 1991.

12. Hollands, K.G.T., Wright, J.L., Granqvist, C.G. in: Solar Energy: "The State of the Art, J. Gordon (Ed.), James \& James Sci”. Publ., London, UK, pp. 29-107, 2001.

13. Schwartz-Schampera, U., Herzig, P.M., Indium: "Geology, Mineralogy", and Economics, Springer, Berlin, Germany, 2002.

14. Solis, J., Hoel, A., Lantto, V., Granqvist, C.G., "J. Appl". Phys. 89, 2001, pp. 2727.

15. Gutarra, A., Azens, A., Stjerna, B., Granqvist. C.G., "Appl. Phys". Lett. 64, pp.1604, 1994.

16. Granqvist. C.G., "Solar Energy Mater". Solar Cells 60 pp.201, 2000.

17. Granqvist. C.G., Avendaño, E., Azens, A., Thin Solid Films 442 pp. 201, 2003.

18. Talledo, A.M., Andersson., Granqvist, C.G. "J. Mater". Res. 5, pp. 1253, 1990.

19. Talledo, A.M., Talledo, A.M., Andersson., Granqvist, C.G., "J. Appl". Phys. 69, pp. 3261, 1991.

20. Talledo, A.M., Stjerna, B., Granqvist, C.G., “Appl. Phys". Lett. 65, pp.2774, 1994.

21. Talledo, A.M., Granqvist, C.G., "J. Phys. D: Appl”. Phys. 27 (1994) 2445.

22. Talledo, A.M., Granqvist, C.G., "Appl. Phys". "A 60", pp. 521, 1995.

23. Talledo, A.M., Granqvist, C.G., "J. Appl". Phys. 77, pp.4655, 1995.

24. Estrada, W., Andersson, A.M., Granqvist, C.G., "J. Appl”. Phys. 64, pp. 3678, 1988.

25. Estrada, W. Andersson, A.M. Granqvist, C.G., "J. Mater". Res. 6, pp. 1715, 1991.

26. Backholm, J., Azens, A., Niklasson, G.A.,"Solar Energy Mater". Solar Cells 90 (2006) 414.

27. Backholm, J., Avendano, E.,Azens, A.,Azevedo,G. de M., Colonel, E., Niklasson, G.A., Granqvist,C.G.,"Solar Energy Mater". Solar Cells 92,pp.91, 2008.

28. Avendaño, E., Azens, A., Niklasson, G.A. Granqvist,C.G., "Solar Energy Mater". Solar Cells 84 (2004) 337.

29. Deb, S.K.,"Solar Energy Mater". Solar Cells 39 (1995) 191.
30. Deb. S.K.,'Solar Energy Mater". Solar Cells 92, pp.245, 2008.

31. Azens, A., Kullman, L., Granqvist, C.G., "Solar Energy Mater". Solar Cells 76, pp. 147, 2003.

32. Granqvist, C.G.,"Nature Mater". 5, pp. 89,2006.

33. Granqvist, C.G., in:"Reactive Sputter Deposition”, D. Depla, S. Mahey (Eds.), Springer Series in Materials Science, Springer, Berlin, Heidelberg, Germany, Vol. 109, pp.485-496, 2008.

34. Thornton, Ann, J.A., "Rev. Mater". Sci. 7 pp, 239, 1977.

35 Rodríguez, J., Gómez, M., Lu, J., Olsson, E., Granqvist, C.G., "Adv. Mater". 12 pp. 341,2000

36 Azens, A., Granqvist, C.G., "J. Solid State Electrochem". 7 pp. 64, 2003.

37 Green, M.A., Emery, K., Hishikawa, Y., Warta, W., "Progr. Photovoltaics: Res. Devel". 17, pp.85, 2009.

38 Roos, A., Persson, M.-L., Platzer, W. Köhl, M. "in Proc. Glass Processing Days", Tampere, Finland, pp. 566-569, 2005.

39 Persson, M.-L., "Windows of Opportunities: The Glazed Area and its Impact on the Energy Balance of Buildings”, $\mathrm{PhD}$ Thesis, Uppsala University, 2006.

40 Lee, E.S., Selkowitz, S.E., Clear, R.D., Di Bartolomeo, D.L., Klems, J.H., Fernandes, L.L., Ward, G.J., Inkarojrit, V., Yazdanian, M., "Advancement of Electrochromic Windows", California Energy Commission, PIER, CEC-500-2006052, 2006.

41 Clear, R.D., Inkarojrit, V., Lee, E.S., "Energy Buildings" 38, pp. 758, 2006.

42 Jones, A.P. "Atmospheric Environment" 33 pp.4535, 1999.

43 Brown, S.K., “Indoor Air 4”, pp. 12, 1994.

44 http://europa.eu.int/rapid/start/cgi/guesten.ks h?p_action.gettxt=gt\&doc $=I P / 03 / 1278|0|$ RA PID\&lg=EN.

45 World Health Organization, "Indoor Air Pollutants: Exposure and Health Effects", EURO Rep. Stud. 78, 1983, pp.1-42.

46 Horvath, E.P., Cleveland Clinic. "J.Med". 64 pp. 303, 1997.

47 Granqvist, C.G., Buhrman, R.A., "J. Appl”. Phys. 47, pp.2200.1975. 
48 Ederth, J., Smulko, J.M., Kish, L.B., Heszler, P., Granqvist, C.G. "Sensors Actuators" B 113, pp. 310, 2006.

49 Hayashi, in: "Surface Coatings for Advanced Materials", R.P. Agarwala (Ed.), Trans Tech Publ., Uetikon, Switzerland, pp. 153-180, 1997.

50 Naruse, F., Kashu, S., Hayashi, C., in: "Gas Phase Nanoparticle Synthesis", Granqvist, C.G., Kish, L.B., Marlow, W.H., "(Eds.), Kluwer Acad. Publ., Dordrecht", the Netherlands, pp. 29-42, 2004.

51 Söderlund, J., Kiss, L.B.,Niklasson, G.A., Granqvist, C.G., "Phys. Rev". Lett. 80 pp. 2386, 1998.

52 Solis, J.L., Saukko,S., Kish, L.B., Granqvist, C.G., Lantto, V., "Sensors Actuators" B 77, pp. 316, 2001.

53 Solis, J.L., Saukko, S., Kish, L.B., Granqvist, C.G., Lantto, V., "Thin Solid Films" 391, pp. 255, 2001.

54 Solis, J.L., Hoel, A., Kish, L.B., Granqvist, C.G., Saukko, S., Lantto, V. "J. Am". Ceram. Soc. 84, 2001, pp. 1504.

55 Reyes, L.F., Saukko, S., Hoel, A., Lantto, V., "J. Lappalainen, Phys". Scripta T114, pp. 240, 2004.

56 Hoel, A., Reyes, L.F., Saukko, S., Heszler, P., Lantto, V., Granqvist, C.G., "Sensors Actuators" B 105 pp. 283, 2005.

57 Reyes, L.F., Hoel, A., Saukko, S., Heszler, P., Lantto, V., Granqvist, C.G., "Sensors Actuators" B117, pp. 128, 2006.

58 Heszler, P., Ionescu, R., Llobet, E., Reyes, L.F., Smulko, J.M., Kish, L.B., Granqvist, C.G., "Phys. Stat. Solidi" B 244, pp. 4331, 2007.

59 Luyo, C., Ionescu, R., Reyes, L.F., Topalian, Z., Estrada, W., Llobet, E., Granqvist, C.G., Heszler, P., "Sensors Actuators" B 138, pp. 14, 2009.

60 Solis, J.L., Kish, L.B., Vajtai, R., Granqvist, C.G., Olsson, J., Schnürer, J., Lantto, V., "Sensors Actuators" B 77, pp. 312, 2001.

61 Kish, L.B., Li, Y., Solis, J.L., Marlow, W.H., Vajtai, R., Granqvist, C.G. Lantto, V., Smulko, J.M., Schmera, G., "IEEE Sensors" J. 5, pp. 671, 2005.

62 Lantto, V., Saukko, S., Toan, N.N., Reyes, L.F., Granqvist, C.G., "J. Electroceramics" 13, pp. 721, 2004.
63 Ionescu, R., Hoel, A., Granqvist, C.G., Llobet, E., Heszler, P., "Sensors Actuators", B 104, pp. 124, 2005.

64 Ionescu, R., Hoel, A., Granqvist, C.G., Llobet, E., Heszler, P., "Sensors Actuators" B 104, pp.132, 2005.

65 Kish, L.B. Vajtai, R., Granqvist, C.G., "Sensors Actuators", B 71, pp. 55, 2005.

66 Kaneko, M., Okura, I.,(Eds.), "Photocatalysis: Science and Technology", Springer, Berlin, 2002.

67 Wang, R., Hashimoto, K., Fujishima, A., Chikuni, M., Kojima, E., Kitamura, A., Shimohigoshi, M., Watanabe, T., "Nature 388, pp. 431, 1997.

68 Nosaka, A.Y., Kojima, E., Fujiwara, T., H. Yagi, H. Akutsu, Y. Nosaka, J., "Phys. Chem". B 107, pp. 12042, 2003.

69 Yu, J., Zhou, M., Yu, H., Zhang, Q., Yu, Y., "Mater. Chem. Phys. 95", pp. 193, 2006.

70 Rodríguez, J., Gómez, M., Lindquist, S.E., Granqvist, C.G., "Thin Solid Films 360", pp. 250, 2000.

71 Rodríguez, J., Gómez, M., Niklasson, G.A., Lindquist, S.-E., Granqvist, C.G., “J. Mater". Sci. 36, 3699, 2001.

72 Rodríguez, J., Gómez, M., Ederth, J., Niklasson, G.A., Granqvist, C.G., "Thin Solid Films 365", pp. 119, 2000.

73 Rodríguez, J., Gómez, M., Niklasson, Granqvist, G.A., "J. Phys. D: Appl. Phys". 33, pp.24, 2004.

74 Mattson, A., Leideborg, M., Larsson, K., Westin, G., Österlund, L., "J. Phys. Chem". B 110, pp.1210, 2006.

75 Asahi, R., Morikawa, T., Ohwaki, T., Aoki, K., Taga, Y., "Science 293, pp. 269, 2001.

76 Lindgren, T., Mwabora, J.M., Avendaño, E., Jonsson, J., Hoel, A., Granqvist, C.G., Lindquist, S.-E., "J. Phys.Chem. B 107, pp. 5709, 2003.

77 Torres, G.R., Lindgren, T., Lu, J., Granqvist, C.G., Lindquist, S.-E. "J. Phys. Chem. B 108, pp. 5995, 2004.

78 Mwabora, J.M., Lindgren, T., Avendaño, E., Jaramillo, T.F., Lu, J., Lindquist, S.E., Granqvist, C.G., "J. Phys. Chem. B 108, pp. 20193, 2004.

79 Gómez, M., Rodríguez, J., Lindquist, S.E., Granqvist, C.G., "Thin Solid Films 342, pp. 148, 1999.

80 Gómez, M., Rodríguez, J., Tingry, S., Hagfeldt, A., Lindquist, S.-E., Granqvist, 
C.G., "Solar Energy Mater". Solar Cells 59, pp. 277, 1999.

81 Gómez, M., Magnusson, E., Olsson, E., Hagfeldt, A., Lindquist, S.-E., Granqvist, C.G., "Solar Energy Mater". Solar Cells 62, pp. 259, 2000.

82 Gómez, M.M., Lu, J., Solis, J.L., Olsson, E., Hagfeldt, A., Granqvist, C.G., "J. Phys. Chem". B 104, pp. 8712, 2000.
83 Gómez, M.M., Lu, J., Olsson, E., Hagfeldt, A., Granqvist,C.G., "Solar Energy Mater". Solar Cells 64, pp. 385, 2000.

84 Gómez, M.M., Beerman, N., Lu, J., Olsson, E., Hagfeldt, A., Granqvist, C.G., "Solar Energy Mater". Solar Cells 76, pp. 37, 2003. 